\title{
Research \\ Coupled Vulnerability and Resilience: the Dynamics of Cross-Scale Interactions in Post-Katrina New Orleans
}

\author{
$\underline{\text { Kevin F. Gotham }}^{1}$ and Richard Campanella ${ }^{1}$
}

\begin{abstract}
We investigate the impact of trauma on cross-scale interactions in order to identify the major social-ecological factors affecting the pace and trajectory of post-Katrina rebuilding in New Orleans, Louisiana, USA. Disaster and traumatic events create and activate networks and linkages at different spatial and institutional levels to provide information and resources related to post-trauma recovery and rebuilding. The extension, intensification, and acceleration of cross-scale linkages and interactions in response to trauma alter organizational couplings, which then contribute to the vulnerability and resilience of social-ecological systems. Rather than viewing urban ecosystems as either resilient or vulnerable, we conceptualize them as embodying both resilient and vulnerable components. This integrated approach directs analytical attention to the impact of sociolegal regulations, government policies, and institutional actions on resilience and vulnerability, which are also systemic properties of urban ecosystems.
\end{abstract}

Key Words: disaster; Hurricane Katrina; New Orleans; resilience; trauma; vulnerability

\section{INTRODUCTION}

Resilience and vulnerability are concepts scholars have developed to explain the interconnections, reciprocal effects, and feedbacks among human and natural systems. Resilience studies seek to explain how and under what conditions ecological and human communities adapt and adjust, or transform and innovate in response to a shock or traumatic event (Berkes et al. 2003, Brand and Jax 2007, Norris et al. 2008, Resilience Alliance 2009, Gunderson 2010). The term "vulnerability" represents the geographical, economic, political, or social susceptibility, predisposition, or risk factor of a group or community to damage by a hazardous condition. Vulnerability studies examine the origin of hazards within coupled systems, the different capacities of social-ecological systems to respond to hazards, and the co-existence of adaptive and maladaptive couplings in vulnerable systems (Blaikie et al. 1994, Comfort 1999, Cutter 2001, Bankoff 2003, Pelling 2003). What unites the diverse work of both resilience and vulnerability perspectives is the "overriding concern with the response of systems to stress or perturbations" (Miller et al. 2010). Vulnerability and resilience approaches emphasize the interaction between endogenous and exogenous processes in the stabilization and transformation of social-ecological systems.

Trauma refers to an extraordinary and potentially dangerous and life changing event linked to reactions and coping including but not limited to human responses (Figley 2009). It may involve social and ecological disruption and devastation caused by war, terrorist strikes, pandemics, and natural disasters (e.g., fires, drought, hurricanes, floods, heat waves, tornados). Hurricane Katrina and the subsequent failure of the federal levee system in New Orleans on 29 August 2005 presents a prime case study of the impact of trauma on a major urban area-and on cross-scale interactions in the subsequent recovery.

Resilience and vulnerability, as well as the related concepts of adaptation and transformation, reveal both opportunities and challenges facing post-Katrina New Orleans, a disaster impacted urban ecosystem recovering from Hurricane Katrina, the Great Recession, and the Deepwater Horizon oil spill in 2010. The paradoxical pairing struck the authors of a recent Brookings Institution report: "[D]espite sustaining three 'shocks' in the last five years, greater New Orleans is rebounding and, in some ways, doing much better than before" (Liu and Plyer 2010:1). "Entrepreneurship has spiked[,] surpassing the rate of individuals starting businesses nationally after having lagged the nation for nearly 10 years [;] average wages in greater New Orleans grew by nearly 14 percent in the last five years, catching up to the national average" (Liu and Plyer 2010:1). In addition, the median household income grew by four percent during 1999-2008, to US\$47,585, despite declines nationally. The report concludes that 'greater New Orleans has become more 'resilient,' with increased civic capacity and new systemic reforms, better positioning the metro area to adapt and transform its future" (Liu and Plyer 2010:1-2).

Yet others lament the region's vulnerabilities. Despite billions of dollars spent rebuilding and upgrading levees and floodwalls, researchers contend the flood protection system remains inadequate for powerful hurricanes (Freudenburg et al. 2009). Since Katrina, housing costs and crime have increased dramatically, contributing to neighborhood instability and social conflict. Housing has moved beyond reach of the working class, with 58 percent of renters paying more than 35 percent of pre-tax income on rent and utilities. In addition, economic sectors such as petro-chemical and 
shipping have eliminated thousands of jobs over the last three decades, while new jobs have increasingly sprawled to the suburbs and exurbs and productivity remains stagnant (Gotham and Greenberg 2008, Plyer and Campanella 2010). The Deepwater Horizon oil disaster "may further weaken legacy industries, and exposes the vulnerability of these sectors to offshore or water-related catastrophes" (Liu and Plyer 2010:9).

We examine the extension, intensification, and acceleration of cross-scale interactions in the aftermath of Katrina to reveal the connections between resilience and vulnerability in socialecological systems. By "cross-scale interactions" we mean influences, connections, and networks among institutions, government agencies, and networks to facilitate the flow of recovery information and resources. Cross-scale interactions imply the (1) extension or stretching of disaster recovery activities across borders, (2) the intensification or magnitude of recovery activities and flows of investment and resources to encourage rebuilding, and (3) the velocity or speed of flows, activity, and interchanges to accelerate post-disaster recovery and rebuilding. Charting the extension, intensity, and velocity of cross-scale interactions involves identifying how and to what extent traumatic events affect patterns and processes of both vulnerability and resilience within and across urban ecosystems. Cross-scale interactions are the communicatory and fiscal infrastructure through which government agencies and organizations circulate and transmit information and resources to facilitate post-disaster recovery and rebuilding. Rather than viewing urban ecosystems as either resilient or vulnerable, we conceptualize them as embodying both resilient and vulnerable components. Vulnerability and resilience are an interplay that presuppose each other-a duality, not a dualism. They are products of cross-scale linkages of policies, socio-legal regulations, networks, and organizations that facilitate some forms of action and decisionmaking while discouraging others. Cross-scale interactions can alter organizational couplings, leading to adaptive couplings that promote resilience, adjustment, and innovation, but can also reinforce maladaptive couplings, which in turn can produce vulnerabilities to future stress and trauma.

\section{VULNERABILITY AND RESILIENCE IN POST- TRAUMA URBAN ECOSYSTEMS}

This analysis builds on scholarly works that have used urban ecosystem analysis in examining change and stability in patterns and processes of post-trauma social and ecological recovery (see Ernstson et al. 2010a, b, Gunderson 2010). Urban ecosystems analysis emphasizes interactions between cities and their environments. Unlike natural ecosystems, however, urban ones are affected additionally by culture, infrastructure, personal behavior, politics, economics, and social organization (Pickett et al. 2001, Grimm and Redman 2004). Central to urban ecosystems analysis is the view that "ecological" and "social" factors are "fundamentally combined" (Swyngedouw 2004:11), and display "conjoint constitution" or "mutual contingency" (Freudenburg et al. 1995). Rather than viewing humans as outside or apart from ecosystems, humans are agents of change acting within socialecological systems (Grimm et al. 2000, Grimm and Redman 2004). As noted by the U.S. Long-Term Ecological Research Network (LTER 2007:II-4), ecosystems "self-organize from evolved components; interactions of slow processes with fast ones, and big processes with small ones, [to] create much of the pattern and dynamics that we observe." A major assumption of social-ecological research is that urban ecosystems are "coupled human and natural systems" (e.g., Liu et al. 2007) or "social-ecological systems" (Walker and Meyers 2004, Folke 2007) that exhibit nonlinear dynamics with thresholds, reciprocal feedback loops, time lags, vulnerabilities, resilience, and heterogeneity. This important point suggests that we can conceptualize urban ecosystems as entities with nested hierarchies in which people and nature interact reciprocally across diverse organizational, spatial, and temporal levels.

Vulnerability and resilience are central concepts and approaches to understanding the response of urban ecosystems to trauma (Miller et al. 2010). Kasperson et al. (2005), Adger (2006), and Gallopín (2006) identify the major concepts of exposure, sensitivity, coping, and adaptive capacity as dominant in many studies of disasters, risk, poverty, and climate change. Rather than viewing vulnerability as a direct outcome of a perturbation or stress, the work of Blaikie et al. (1994), Downing et al. (2005), and Eakin and Luers (2006), among others, examines how policy-makers, organizations, political economic processes, and power relations influence characteristics of exposure, susceptibility, and coping capacity. Although vulnerability analyses differ in their theoretical intent and scales of analysis, they tend to examine how factors such as social class, race/ethnicity, gender, and age shape conditions and perceptions of vulnerability (Freudenburg 1993, Perrow 1997, Klinenberg 2002, Auyero and Swinstun 2008). Scholars recognize that political, social, and economic processes influence estimates of vulnerability and peoples' ability to understand vulnerability and assess hazards. Such a perspective eschews a notion of vulnerability as an a priori social condition and examines the social and political construction of vulnerability assessments, interpretations, and perceptions.

Fig. 1 shows our conceptual framework for explaining the effects of trauma on cross-scale interactions, and the particular effects of these interactions on resilience and vulnerability. The figure suggests that we can understand the concepts of resilience and vulnerability only in relation to one another since both are properties of a social-ecological system. We view vulnerability as a condition that encompasses the features of exposure, susceptibility, and coping capacity. Power relations, socio-cultural processes, and political economy 
Fig. 1. Conceptual framework for explaining the impact of trauma on social-ecological resilience and vulnerability.

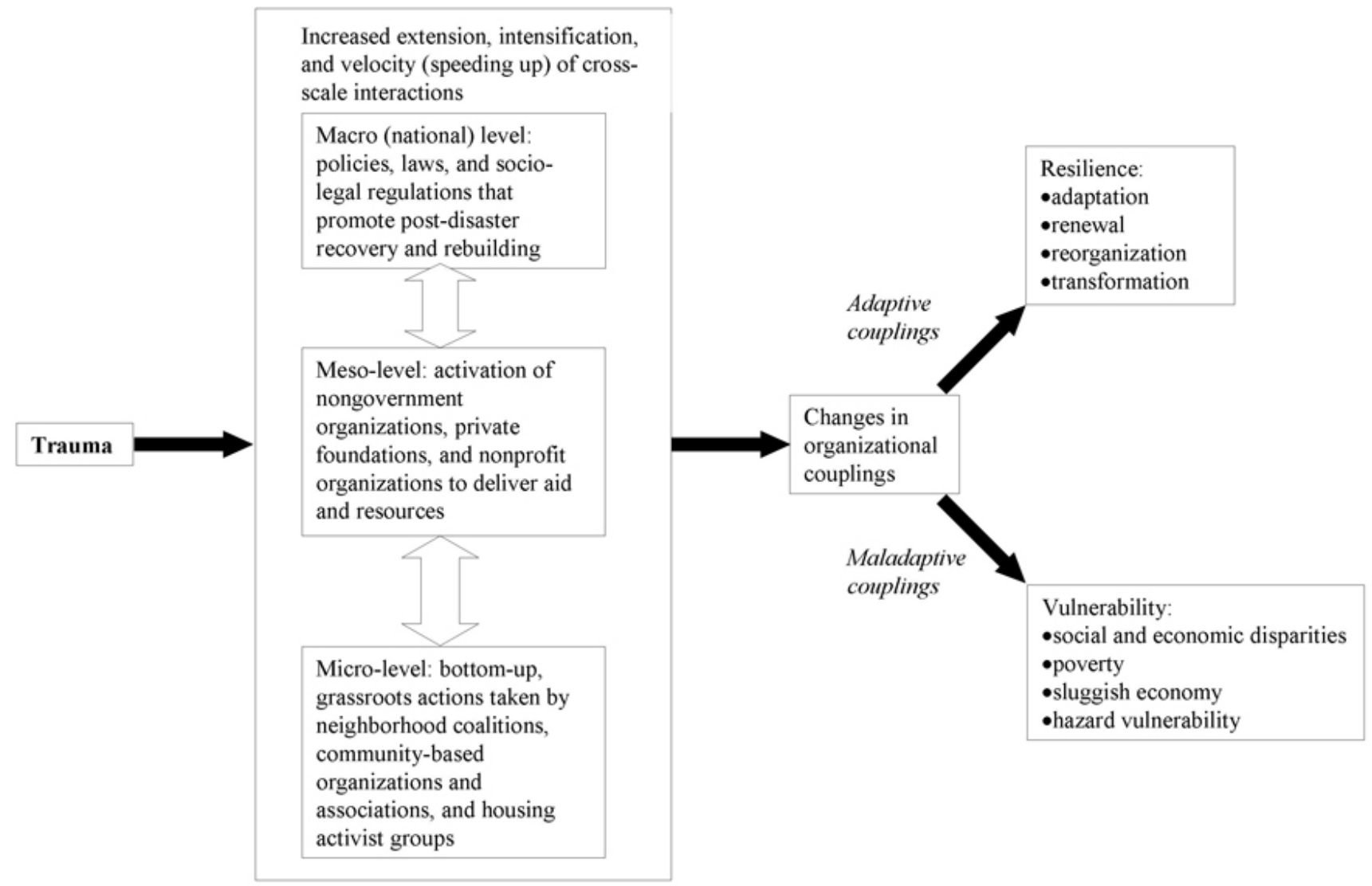

shape and influence the variability of these features, making some groups more susceptible to stress and trauma than others. We view resilience as incorporating three factors: the ability to absorb shocks and trauma, the ability to bounce back and recover, and the ability to learn, adapt, and innovate. Paraphrasing Folke (2006), resilience refers to the ability of social-ecological systems to cope with and adapt to uncertainty and surprise.

We explain cross-scale interactions in terms of the extension, intensification, and acceleration of government actions, interchanges between public and private actors, socioeconomic activities, and flows and networks of investment and finance. Acknowledging these dimensions suggests an interpretive schema for describing cross-scale interactions, evaluating the impact of different kinds of public and private activities, and assessing what is novel about the pace and trajectory of the post-Katrina recovery and rebuilding process. "Flows" refer to the movement of commodities, money, people, and information across space and time, while "networks" refer to patterned interactions among agents, organizations, and activities. In this sense, cross-scale interactions involve increased interregional interconnectedness, a widening reach of networks of social activity, and the possibility that local events and actions (by individuals, corporations, and governments) can have far-reaching and long lasting consequences.

Increases in the extension, intensification, and acceleration of cross-scale interactions can influence the pace and trajectory of both post-disaster ecological and community system recoveries (Liu et al. 2007). On the one hand, cross-scale interactions can promote adaptive couplings that involve processes of coordination, inter- and intra-government collaboration, social learning, knowledge sharing and integration, trust building, and conflict resolution (Folke et al. 2005, Olsson et al. 2006). On the other hand, cross-scale interactions can promote maladaptive couplings that slow recovery, limit capacity for social-ecological renewal, and reinforce patterns and processes of vulnerability and unsustainable development. Maladaptive couplings imply different forms of cross-scale interactions that perpetuate 
Fig. 2. Mississippi River-Gulf Outlet Canal.

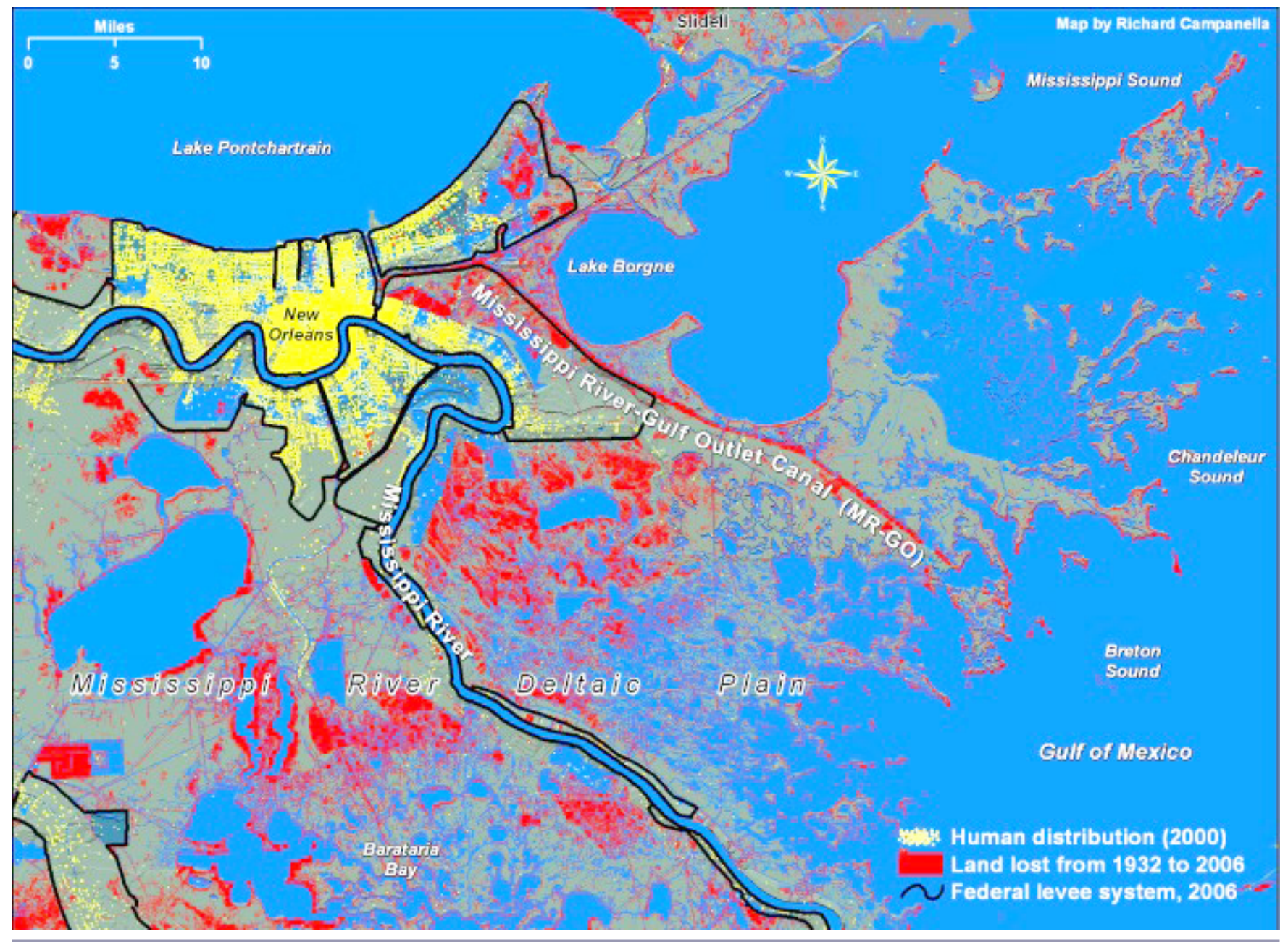

social-ecological inequality, generate and exacerbate group struggles and antagonisms, and impede conflict resolution. Few studies have focused on the coupled nature of vulnerability and resilience in post-trauma urban ecosystems. We focus on how cross-scale interactions can generate both adaptive and maladaptive couplings in post-trauma urban ecosystems.

We also recognize that resilience and vulnerability are not antonyms. Rather, urban ecosystems exhibit both vulnerable and resilient qualities that are oftentimes products of past and present cross-scale interactions. Three past cross-scale interactions linking local actions with federal policies and socio-legal regulations were important. First, the Flood Control Act of 1965 authorized the Army Corps of Engineers to create a series of joint federal, state, and local partnerships in which governments designed and built levees, floodwalls, and other flood control structures to protect the region from hurricane storm surges. While there were major alterations in these arrangements and designs over the decades, the overall intent was to encourage private investment in building urban infrastructure in the wetlands. Second, the establishment of the National Flood Insurance Program (P.L. 90-448) in 1968 served as a major socio-legal mechanism to urbanize the wetlands by subsidizing private insurers to write policies in areas at risk for flooding and hurricane damage. Third, the building of the Mississippi River Gulf Outlet (MR-GO) navigation canal in the 1960 s operated as a conduit to dramatically increase salinity in the marshes and thereby devastate the wetlands (Fig. 2). Before closure in 2008, MRGO had contributed to the erosion of 8,094-26,305 hectares (20,000-65,000 acres) of wetlands, as much as 259 of the 1,295 square kilometers (100 of the 500 square miles) of wetlands that had previously stood to the southeast of New Orleans, an area that was in the bull's eye of Hurricane Katrina's storm surge that engulfed the city and region. All of these 1960s developments interacted with the long-term degradation of surrounding wetlands through a combination of upstream dams and river channeling, and oil and gas exploration in southern Louisiana. 
Table 1. Funding history of Community Development Block Grant supplemental appropriations for Hurricane Katrina disaster relief.

\begin{tabular}{|c|c|c|}
\hline Public law & Funding & Intended use of funds \\
\hline $\begin{array}{l}\text { P.L. 109-148. Department of } \\
\text { Defense, Emergency Supplemental } \\
\text { Appropriations to Address } \\
\text { Hurricanes in the Gulf of Mexico, } \\
\text { and Pandemic Influenza Act, } 2006 \\
\text { (December 30, 2005) }\end{array}$ & $\begin{array}{l}\text { US } \$ 11.5 \text { billion (Louisiana } \\
\text { receives } \$ 6.2 \text { billion) }\end{array}$ & $\begin{array}{l}\text { Hurricanes Katrina, Rita, and Wilma. Community Development } \\
\text { Block Grant (CDBG) funding for activities and necessary expenses } \\
\text { related to disaster relief, long-term recovery, and restoration of } \\
\text { infrastructure in the most impacted and distressed areas related to the } \\
\text { consequences of hurricanes in the Gulf of Mexico in } 2005 \text { in states } \\
\text { for which the President declared a major disaster under title IV of the } \\
\text { Robert T. Stafford Disaster Relief and Emergency Assistance Act (42 } \\
\text { U.S.C. } 5121 \text { et seq.). (119 Stat. 2780) }\end{array}$ \\
\hline $\begin{array}{l}\text { PL 109-234. Emergency } \\
\text { Supplemental Appropriations Act } \\
\text { for Defense, the Global War on } \\
\text { Terror, and Hurricane Recovery Act } \\
\text { of } 2006\end{array}$ & $\begin{array}{l}\text { US } \$ 5.2 \text { billion (Louisiana } \\
\text { receives US } \$ 4.2 \text { billion) }\end{array}$ & $\begin{array}{l}\text { Second supplemental appropriation of CDBG funding for activities } \\
\text { and necessary expenses related to disaster relief, long-term recovery, } \\
\text { and restoration of infrastructure in the most impacted and distressed } \\
\text { areas related to the consequences of hurricanes in the Gulf of Mexico } \\
\text { in } 2005 \text { in states for which the President declared a major disaster } \\
\text { under title IV of the Robert T. Stafford Disaster Relief and Emergency } \\
\text { Assistance Act (42 U.S.C. } 5121 \text { et seq.). (119 Stat. 2780) }\end{array}$ \\
\hline $\begin{array}{l}\text { P.L. 110-116. Department of } \\
\text { Defense Appropriations Act for } \\
\text { FY2008 (November 2007) }\end{array}$ & US $\$ 3$ billion (for Louisiana) & $\begin{array}{l}\text { CDBG funding specifically for the State of Louisiana's "Road Home' } \\
\text { homeowner assistance program }\end{array}$ \\
\hline
\end{tabular}

Sources: Boyd (2006), HUD (2006)

In sum, the confluence of suburbanization, growth pressures, and ecological degradation of the surrounding wetlands in the New Orleans region after the 1960s created long-term environmental, social, and economic problems that involve complex feedback loops. Past federal, state, and local government interactions encouraged suburban development in the swamps and marshes, which increased vulnerability of human settlements and infrastructure to storm surge events and flooding. Thus, Hurricane Katrina was a trigger event and not the actual cause of the massive flooding and subsequent property damage that affected the New Orleans region. New Orleans' poorly designed and constructed levees and floodwalls collapsed under moderate hurricane conditions due to the feedback effects of past cross-scale interactions. The transformation of the regional landscape with levees, canals, floodwalls, and real estate development in the swamps disguised risk in the built environment and generated future vulnerabilities to hurricanes and flood hazards. These points connect with the work of Bankoff (2007), who notes that crossscale interactions and their effects on urban vulnerability and resilience have a historical trajectory. Social-ecological processes interact over temporal and spatial scales simultaneously, suggesting that we must understand crossscale interactions in historical as well as spatial context.

\section{CROSS-SCALE PROCESSES OF POST-KATRINA RENEWAL AND RECOVERY}

Since Katrina, the federal government has relied on preexisting as well as newly developed funding programs to encourage cross-scale interactions among government agencies, private firms, and nonprofit organizations to facilitate recovery and rebuilding. Congress has authorized almost US\$10 billion for the Army Corps of Engineers to repair and design the levee system that is supposed to protect New Orleans and surrounding parishes from storm surge flooding caused by hurricanes with a one percent chance of occurring in any year, often referred to as a 100-year storm. The largest source of grant assistance has been the Community Development Block Grant program, which provides funding for neighborhood revitalization and housing rehabilitation activities and affords states broad discretion and flexibility in deciding how to allocate federal funds and for what purposes. To date, Congress has appropriated US\$19.7 billion for Gulf Coast rebuilding assistance, the largest amount in the history of the program (Table 1).

The federal government has also used long-established grant programs such as the Temporary Assistance for Needy Families and the Social Services Block Grant programs to supply financial and human recovery assistance to Louisiana residents. There have also been several newly created grants with emergency supplemental funds designed to provide human recovery assistance to hurricane-affected areas. Some of these grants include the Department of Health and Human Services' Primary Care Access and Stabilization Grant and the Department of Housing and Urban Development's (HUD) Disaster Housing Assistance Program.

Table 2 provides an overview of selected federal funding programs that facilitate Gulf Coast recovery. It provides evidence of the diversity of policies and programs that the 
Table 2. Selected federal funding programs providing support to victims of Hurricane Katrina.

\begin{tabular}{l}
\hline Federal funding programs \\
Temporary Assistance for Needy Families (TAN \\
Community Development Block Grant (CDBG)
\end{tabular}

Social Services Block Grant

\section{CDBG Workforce Housing Grant}

\section{CDBG Entitlement Communities}

Low-income Home Energy Assistance Program

Federal Emergency Management Agency (FEMA) Community Disaster Loans

FEMA Voluntary Agency Liaison (VAL)

Office of the Federal Coordinator (OFC) for Gulf Coast Rebuilding

Gulf Opportunity Zone Low-Income Housing Tax Credit Program

Primary Care Access and Stabilization Grant
Description

The Department of Health and Human Services' (HHS) TANF program provides assistance and work opportunities to needy families by granting states, territories, and tribes federal funds to develop and implement their own welfare programs. The Department of Housing and Urban Development's (HUD) CDBG program provides grants to help cities, counties, and states recover from presidentially declared disasters, especially in low-income areas, subject to availability of supplemental appropriations.

HHS distributes Social Services Block Grant funds to enable states to provide social services to residents. Such services may include daycare and protective services for children or adults, special services to persons with disabilities, adoption, case management, health-related services, transportation, foster care for children or adults, substance abuse services, housing, home-delivered meals, independent/transitional living, employment services, or any other social services found necessary by the state.

This HUD grant targets housing to those between 60 percent and 120 percent of the area median income.

Through this CDBG program HUD allocates annual grants to large cities and urban counties to develop sustainable communities.

The Low-income Home Energy Assistance Program is a federally funded block grant program administered by HHS and implemented at the state level. The grant serves individuals and families from low-income households who seek assistance for their home energy bills.

FEMA offers these loans to any eligible jurisdiction in a designated disaster area that has suffered a substantial loss of tax and other revenue. The jurisdiction must demonstrate a need for financial assistance to perform its governmental functions to maintain essential services such as public schools, and fire and police services. As the primary liaison to the nonprofit community, VALs are responsible for initiating and maintaining a working relationship between FEMA; federal, state, and local agencies; and nonprofit organizations. As of 2009, FEMA's VAL program had 10 memorandums of understanding with nonprofit organizations charged with implementing FEMA programs. These nonprofits include National Voluntary Organizations Active in Disaster, American Red Cross, The Salvation Army, United Methodist Committee on Relief, Adventists Community Services, Church World Service, Feeding America, Mennonite Disaster Service, Northern American Mission Board-Southern Baptist Convention, and Operation Hope USA.

In February 2008, the OFC and FEMA formed a Transparency Initiative, a webbased information sharing network to track the status of selected public infrastructure building projects (such as school or hospital) by providing detailed information on the Public Assistance Grants funds allocated for the project. In 2009, the OFC partnered with the White House to develop intra-government (horizontal) networks that link the White House Office of Faith-Based and Neighborhood Partnership centers with 12 federal agencies including the Department of Homeland Security, HUD, and the Small Business Administration. These agencies, in turn, helped buttress and reinforce cross-scale networks with local community and faith-based organizations through the provision of temporary staff, training, and technical assistance.

HUD designed the Gulf Opportunity Zone Low-Income Housing Tax Credit program to provide tax incentives for developing affordable rental housing along the Gulf Coast.

HHS awarded the Primary Care Access and Stabilization Grant to Louisiana to help restore primary health care services to low-income populations. 


\section{Disaster Housing Assistance Program \\ Community Mental Health Services Block Grant}

Continuum of Care Program

Disaster Case Management Pilot Program

Katrina Aid Today (KAT)
This HUD program provides temporary long-term housing rental assistance and case management for households affected by Hurricanes Katrina and Rita. The Substance Abuse and Mental Health Services Administration's Community Mental Health Services Block Grant is awarded to states to provide mental health services to people with mental disorders.

HUD's Continuum of Care Program is a set of three competitively awarded programs (Supportive Housing Program, Single Room Occupancy Program, and Shelter Plus Care Program) created to address the problems of homelessness in a comprehensive manner with other federal agencies.

FEMA uses funds from its Disaster Relief Fund to provide state and local governments with federal disaster recovery assistance. The state-managed Disaster Case Management Pilot Program is intended to help households in Louisiana and Mississippi achieve permanent housing.

FEMA awarded a 2-year case management grant that channeled US\$66 million of foreign donations to the United Methodist Committee on Relief (UMCOR). UMCOR used the grant to establish KAT, a national consortium of nine social service and voluntary organizations, to provide case management services to victims of Hurricane Katrina. At the completion of its grant funded activity in March 2008, KAT had enabled case management services for approximately 73,000 households. As the umbrella grants manager, UMCOR provided financial compliance monitoring, technical assistance, and training to the nine consortium members.

Source: GAO (2010)

federal government has used and created to increase the extension, magnitude, and speed of disaster recovery and rebuilding activities and resources across scales. Three examples are relevant. First, federal resources have encouraged faith-based organizations to mobilize and assist other nonprofits' access to available federal funds in order to deliver much needed services. Using US\$66 million in Federal Emergency Management Agency (FEMA) channeled foreign donations, the United Methodist Committee on Relief established the Katrina Aid Today (KAT), a national consortium of nine sub-grantees, to distribute grants to other nonprofit organizations. At the completion of its grant-funded activity in March 2008, KAT had enabled case management services for approximately 73,000 households.

Second, the National Response Framework designates the FEMA Voluntary Agency Liaisons (VAL) as the primary liaisons for initiating and maintaining a working relationship between FEMA; federal, state, and local agencies; and nonprofit organizations. VALs helped expand cross-scale networks of activity by linking the federal government to the nonprofit sector through state-level intermediaries. As of 2009, FEMA's VAL program had 10 memorandums of understanding with nonprofit organizations charged with implementing FEMA programs. These nonprofits include National Voluntary Organizations Active in Disaster, American Red Cross, The Salvation Army, United Methodist Committee on Relief, Adventists Community Services, Church World Service, Feeding America, Mennonite Disaster Service, Northern American Mission Board-Southern Baptist Convention, and Operation Hope USA.
Third, the Office of the Federal Coordinator (OFC) for Gulf Coast Rebuilding in the Department of Homeland Security has played a key role in encouraging the formation of new cross-scale interactions and networks of activity through information sharing, grant distribution, and knowledge exchange with nonprofit organizations. In February 2008, the OFC and FEMA formed a Transparency Initiative, a webbased information-sharing network to track the status of selected public infrastructure building projects (such as school or hospital) by providing detailed information on the Public Assistance Grants funds allocated for the project. In 2009, the OFC partnered with the White House to develop intragovernment (horizontal) networks that link the White House Office of Faith-Based and Neighborhood Partnership centers with 12 federal agencies, including the Department of Homeland Security, HUD, and the Small Business Administration. These agencies, in turn, helped buttress and reinforce cross-scale networks with local community and faith-based organizations through the provision of temporary staff, training, and technical assistance (GAO 2010).

\section{Acceleration of cross-scale interactions}

Recent advances in computing and communications technology have been central to accelerating cross-scale interactions and flows of activity related to post-disaster recovery and rebuilding. Online disaster response capacities have expanded due to the integration of the Internet with key geospatial technologies such as remote sensing, geographic information systems (GIS), and global positioning systems (GPS). Use of the Internet enhances the delivery of geospatial information to a larger audience, facilitating greater exchange 
of information, and increasing the speed of communication. In the immediate aftermath of Katrina, websites dedicated to assisting evacuees, such as KatrinaCentral.com, Craigslist. org, and nola.com, allowed people in remote and distant places to follow the relief effort. Message boards, such as nola.com, provided information about shelter locations, family tracing, and missing persons. Many displaced persons used wiki software as an organizational tool to create web portals to web pages such as those identifying immediate shelter needs (ShelterFinder) and family tracing (PeopleFinder). In addition, electronic communication and information technologies allowed people to donate money quickly for immediate disaster relief efforts. Nearly one million people visited the American Red Cross website on the Wednesday following Katrina, a figure that was 32 times the average amount of traffic to the nonprofit organization's website (Dang and Burris 2005, Noguchi 2005).

Information and communication technologies that increase the velocity of cross-scale interactions provide for the establishment and routinization of "bridging" links that connect otherwise spatially dispersed and unconnected organizations to diverse networks and flows of post-disaster resources (Tompkins and Adger 2004). The development of GIS, remote sensing, and the Internet accelerate information flows and rapidly diffuse ideas, information, decisions, people, and diverse forms of capital. The increased velocity of diffusion, in turn, multiplies the number of bridging connections between individuals, organizations, groups, and communities. The fast transmission rate allows for quick responses to stresses and threats. The increasing speed of response is typically seen as enhancing resilience and adaptive capacity and reducing vulnerability (e.g., through real-time monitoring, fast delivery of humanitarian aid). More important, the proliferation of bridging connections creates new opportunities for social learning because the various components of the system are able to observe activities in other components. In short, bridging links encourage communities to communicate, exchange information and knowledge, and help foster vertical and horizontal relationships for proactive resilience building (Newman and Dale 2005). By sharing information and knowledge, communities are able to learn and incorporate new behaviors and actions into their repertoires of recovery to create novel and innovative processes and patterns of post-disaster redevelopment (Norris et al. 2008).

Yet there is a dark side to information and communication technologies. Technologies are capable of empowering nefarious or exploitive agents in times of crisis, as revealed by various fabrications and myths that circulated online after Katrina. In the weeks following the disaster, online discussions and media portrayals obsessed on images of social breakdown, lawlessness, and violence. Media outlets described the descent of New Orleans into anarchy with "hundreds of armed gang members killing and raping people" and storm victims shooting at rescue crews (Thevenot and Russell 2005:A1). Various news reporters described the New Orleans Convention Center, which became an unofficial gathering place for storm victims, as "a nightly scene of murders, rapes and regular stampedes" (Thevenot 2005:36). Such reports constructed disaster victims as "lawless, violent, exploitative, and almost less than human" (Tierney et al. 2006:63). Statements made by city officials-including the mayor and police chief-helped fuel some of the more extreme myths of mayhem during the New Orleans disaster, including reports of rampant murder, "babies being raped," and armed thugs taking control (Dwyer and Drew 2005, Pierre and Gerhart 2005:A8, Dynes and Rodriguez 2007). The unsubstantiated and later discredited atrocity tales coming out of New Orleans provided political ammunition to politicians looking to discredit government actions devoted to the recovery effort.

\section{Federal-local linkages and the role of nonprofit organizations}

One notable feature of the post-Katrina rebuilding effort has been the reliance on nonprofit organizations to deliver services. Rather than relying solely on government agencies, the federal government has increasingly partnered with nonprofit organizations because of their flexibility, diversity of functions, quick response rates, and extant and oftentimes trusting relationships with local communities (GAO 2007). Congress passed legislation to encourage nonprofit organizations to create networks of activity for the delivery of federal assistance to Gulf Coast residents. Most notably, provisions in the Post-Katrina Emergency Management Reform Act of 2006 expanded eligibility requirements for nonprofit organizations to receive FEMA grant assistance. In order to deploy more highly trained workers to impacted communities, the federal Corporation for National and Community Service waived state matching requirements for sponsoring AmeriCorps workers in Louisiana and counted the cost of housing them as an in-kind match for sponsoring AmeriCorps workers (Corporation for National and Community Service 2005). These program waivers made it easier for nonprofits with limited financial resources to sponsor AmeriCorps workers to increase capacity to serve disaster victims and communities.

Table 3 provides examples of some of the nonprofit organizations that have partnered with the federal government to help build the capacity of direct service providers. These nongovernment partners provide human resources, guidance, training, funding, and technical assistance for Gulf Coast recovery.

The cross-scale post-Katrina rebuilding activities of the nonprofit organizations listed in Table 3 would be difficult to undertake were it not for federal government actions. Federal grant programs have incentivized efforts to create new partnerships and collaborations among nonprofit organizations 
Table 3. Nonprofit organizations involved in post-Katrina rebuilding in New Orleans.

\begin{tabular}{l}
\hline Nonprofit organization \\
National Voluntary Organizations Active in Disaster \\
National VOAD) \\
State VOADs in Louisiana \\
Local/Community VOADs in Louisiana \\
Long-Term Recovery Committees/Organizations in \\
Louisiana
\end{tabular}

Greater New Orleans Disaster Recovery Partnership

Neighborhoods Partnership Network

Louisiana Odyssey House

Catholic Charities Archdiocese of New Orleans

Mercy Family Center

Louisiana Family Recovery Corps

Beacon of Hope Resource Center

Rebuilding Together New Orleans

Louisiana Association of Nonprofit Organizations (LANO)

\section{Mission}

Coalition of national nonprofit organizations that share knowledge and resources throughout the disaster cycle to help disaster survivors and their communities. Members include the American Red Cross and The Salvation Army.

Consortium of voluntary organizations that are active in disasters within the states of Louisiana and Mississippi. Their mission is to foster more effective service to people affected by disaster.

Consortium of voluntary organizations that are active in disasters at the local and community levels

Groups of community leaders, including nonprofit, interfaith, local government, and private sector leaders, whose mission is to identify needs that have not been addressed through insurance or governmental aid and to match up voluntary agency sources and/or local sources for goods and services to meet those needs Coalition of 70+ member agencies, including faith-based, nonprofit, government liaison, and Long-Term Recovery organizations, that serve those impacted in the Greater New Orleans region

Nonprofit organization consisting of a citywide network of neighborhoods that was established after the Hurricane Katrina disaster to facilitate neighborhood collaboration, increase access to government and information, and strengthen the voices of individuals and communities across New Orleans

Organization that provided crisis, mental health, and substance abuse counseling through the use of federal funding

Organization that contracted with the Louisiana State Office of Mental Health and the resulting Louisiana Spirit Hurricane Recovery project, funded by FEMA, to help provide intervention and mental health services to its clients

Organization that provided crisis, mental health, and substance abuse counseling through the use of federal funding

Organization that facilitates human recovery in Louisiana by partnering with human service and nonprofit agencies throughout the state and country to deliver assistance as effectively and efficiently as possible

Nonprofit organization that serves 16 New Orleans neighborhoods and whose mission is to assist homeowners in the City of New Orleans in the rebuilding process

Program of the Preservation Resource Center of New Orleans that focuses on home rehabilitation and community recovery using a combination of volunteer and professional labor funded by corporate, private, and public dollars, volunteers, and help from the AmeriCorps program

Statewide network of nonprofits, foundations, corporations, and individuals dedicated to supporting Louisiana's nonprofit sector. LANO's mission is to strengthen, promote, and build the capacity of nonprofits through education, advocacy, and member services.

Source: GAO (2010)

to provide financial, technical, and support services to Gulf Coast communities. In its 2005-2008 retrospective, the Louisiana Disaster Recovery Foundation reported awarding grants totaling nearly US\$29 million to nonprofit organizations involved in Louisiana's recovery process (GAO 2010:4). Organizations such as the Louisiana Association of Nonprofit Organizations ([LANO] 2005) had an existing communications infrastructure with more than 1000 nonprofits within the state of Louisiana before the 2005 storm. LANO accessed this network following the hurricane to disseminate grant and technical information, provide vital resource referrals, and communicate about available training workshops for nonprofit service providers. At the end of 2009, FEMA officials in Louisiana reported that more than US\$24 million in donated dollars, volunteer hours, and goods had been leveraged through long-term recovery groups to provide permanent housing and address other unmet needs. Also, federal hazard mitigation grants have provided funds to raise homes to base flood elevation levels, and thereby have assisted community efforts to reduce vulnerability to future flooding. In addition, community organizations and networks have transmitted information and thereby increased awareness of 
the importance of purchasing flood insurance. Overall, the organizations listed in Table 3 have played major roles in building a network of adaptive capacities by engaging local people in recovery and mitigation, creating organizational linkages, and establishing new social supports.

In short, federal government policies and programs have been crucial in establishing a series of cross-scale interactions among government agencies and nonprofit organizations to promote coordination and capacity building. Direct and indirect funding programs have helped create, activate, and reinforce vertical and horizontal linkages between governments and secular and faith-based nonprofit organizations to deliver and manage resources to support rebuilding efforts. In the aftermath of Hurricane Katrina, Catholic, Mennonite, Salvation Army, and other faith-based relief groups linked up with large secular nonprofit organizations such as the Red Cross to form the Greater New Orleans Disaster Recovery Partnership (GNODRP), a major relief network that crossed parish lines and embraced an entire region. After most disasters, private, nonprofit relief organizations create country-based networks or roundtables to coordinate their work and share resources. For instance, a Methodist relief agency assisting an earthquake-affected family can go to its country-based roundtable and make request to a partner, perhaps Catholic Charities, for a donation of cash or volunteers from Catholic organizations to help Methodist volunteers support affected families. GNODRP represents the first time in which major religious and secular nonprofit groups established a region-wide network to coordinate work and share resources, including building materials. From 2005 to 2009, the GNODRP distributed more than US\$25 million in aid to more than 1000 families (Nolan 2009).

\section{Cross-scale networks as sources of resilience}

Ecologists and social scientists have long recognized that processes that interact across spatial and temporal scales influence both post-trauma ecological and community system recoveries. Holling (1986) labels a post-disturbance period of renewal and recovery as the "alpha phase," in which the system is most vulnerable to random and chance events. This is also the phase in which many opportunities emerge for enhancing resiliency and reconfiguring the system for growth and development. Gunderson (2010) describes this alpha phase as a "window of opportunity" in which novel actions and innovative changes are possible. Post-trauma situations can be ripe for members to revaluate old patterns and processes of community organization, identify problems and limitations of social-ecological structure and function, and develop alternative plans for recovery and renewal that allow the system to develop in a new and different trajectory (Holling 2001, Berke and Campanella 2006, Masten and Obradovic 2007, Gunderson 2010). The challenge, of course, is for communities and organizations to turn disturbances, disasters, and other forms of trauma into opportunities for reinvention and innovation. As Mutter (2010:1042) has recently asserted, "a disaster that sweeps away shoddy infrastructure can be an impetus to improve roads, hospitals and industry." In considering "deep solutions ... policy-makers must formulate plans to turn disasters into opportunities" (Mutter 2010:1042).

Since Katrina, neighborhood coalitions, nonprofit organizations, and cultural associations have mobilized to form novel collaborations and networks to leverage private and public resources to rebuild New Orleans, increase flood awareness and protection, and maximize community participation to nurture social-ecological resilience. Some of these organizations are described in Table 3. Shortly after the disaster, New Orleans residents formed the Neighborhoods Partnership Network (NPN) as a nonprofit organization consisting of a citywide network of neighborhoods to facilitate neighborhood collaboration, leverage public and private investment, and engage civically. The NPN helped create a "citywide framework to assist communities in accessing limited resources and information while providing connections to other communities that have similar obstacles so that communities can avoid duplicating efforts and work toward shared goals" (http://www.npnnola.com/about/). Important, we view the NPN and the organizations listed in Table 3 as vehicles of community resilience that mobilize emergency and ongoing support services for disaster survivors through both pre-existing and newly created organizational networks This observation corroborates the work of Norris et al. (2008:127), who note that building post-disaster community resilience is a process of "linking a network of adaptive capacities (resources with dynamic attributes) to adaptation after a disturbance." Nonprofit organizations, neighborhood coalitions, and other organizations are characterized by reciprocal links that broaden "the scope of actors, agents, and knowledge that can be marshaled" (Comfort 2005:347) not only for the purpose of community recovery but also for developing new strategies to lessen future disaster risk and vulnerability.

Private foundations have been important institutions in linking the top-down actions of the federal government with the bottom-up actions of grassroots community organizations. During the five years since the flood, the Rockefeller Foundation has awarded 42 grants totaling US $\$ 22$ million to New Orleans civic institutions and organizations, with a special emphasis on enhancing citizen participation. Other foundations such as Brad Pitt's Make It Right (MIR) Foundation have formed networks of local groups and international organizations to seek donations, corporate sponsors, and seed capital to catalyze neighborhood redevelopment. While Pitt is the celebrity spokesperson for the MIR Foundation, much of the planning takes place among the renowned designers and planners within the architecture firms that comprise the organization. Pitt asks foundations, corporations, and individuals to contribute to the project by 
adopting one house, several houses, or a portion of a house through the project website. The mission of the MIR Foundation is to redevelop the Lower Ninth Ward by building a neighborhood of high quality, affordable, and environmentally conscious homes that reflect and promote sustainable development. As of January 2011, MIR had constructed 43 homes, gained worldwide attention for the urban sustainability movement, and - much to its chagrinemerged as a must-see site for bus tours.

Ironically, MIR's decision to rebuild the neighborhood closest to the most severe high-velocity breach flooding, on a site that is mostly below sea level, isolated from the urban core, and adjacent to two risk-inducing humanmade navigation canals, has been criticized by some experts as increasing vulnerability - even as MIR purports to do the exact opposite. Indeed, some voices (both local and outside) questioned the wisdom of rebuilding heavily flooded, low-lying, far-flung subdivisions at all, in light of massive population losses since the 1960s and particularly since Katrina, while others (entirely outsiders) pondered whether the entire city would be better off abandoned or relocated. In nearly every case, the opining voices generally saw their arguments as rational, scientifically substantiated strategies that would increase future resilience and decrease vulnerability. This debate over "shrinking the urban footprint," which played out polemically in the year following Katrina, illustrates how resilience and vulnerability not only co-exist empirically in post-trauma environments, but also perceptually.

Cross-scale interactions not only empower new collective agents such as private foundations but also play a role in generating resilient ecosystem services such as improved mitigation of flooding, freshwater diversion projects, and reintroduced habitats (Ernstson et al. 2010b). The case of the Mississippi River Gulf Outlet (MR-GO), an environmentally deleterious navigation channel opened in 1965, is illustrative. Various parties across scales-from rural citizens to urban environmentalists, from local officials to scientists-have blamed the channel for the erosion of wetlands along Lake Borgne and for expediting hurricane storm surge into Chalmette and New Orleans. After Congress ordered it closed, the Army Corps of Engineers proposed its MR-GO Ecosystem Restoration Plan to protect or rebuild 238 square kilometers (92 square miles) of wetlands over 10 years, beginning as early as 2012. Blocking salt water from the Gulf and creating a freshwater diversion from the Mississippi River into Lake Borgne would keep salinity levels low enough to allow vegetation to take root and thrive. The restoration plan also seeks to reduce erosion and hold soil in place to help healthy cypress forest and wetlands provide additional protection from future storms (Fig. 2).

\section{CROSS-SCALE PATHOLOGIES AND POST- KATRINA VULNERABILITY}

Scholars recognize that cross-scale interactions vary in form and consequence (Cash et al. 2006). On the one hand, they can expedite the delivery of resources to needy communities, mitigate conflict, speed recovery, and build resilience. Olsson et al. (2004) and Tompkins et al. (2002) have hypothesized prerequisites for sustained interaction between stakeholders in resource co-management that include (1) the enabling of constitutional order and legislation, (2) the ability of organizations to monitor and adapt their co-management experiments, and (3) the presence of leaders and agents for change. On the other hand, cross-scale interactions can concentrate power and degrade resources for community resilience. Berkes (2002) draws attention to "cross-scale institutional pathologies" where actions and inactions by powerful stakeholders can undermine trust, breed discontent, and disempower communities. Government agencies can degrade community resilience and perpetuate vulnerabilities by using information and resources from cross-scale interactions to reinforce their political authority, promote narrow self-interests, and exploit disadvantaged groups.

One way in which cross-scale linkages can reproduce human vulnerabilities to trauma is through policies that reinforce and perpetuate socio-spatial inequalities. Louisiana's Road Home program, which gives up to US $\$ 150,000$ in grants to homeowners to rebuild their flooded homes, offers a case study. Over the last several years, housing activists and civil rights groups have alleged that the Road Home program used a discriminatory formula in distributing awards. Under Road Home rules, officials calculated rebuilding grants on the basis of the lower of two figures: the pre-storm market value of the home, or the cost of the storm damage to the house. By definition, therefore, homeowners received sufficient assistance to rebuild their homes if the cost of damage was lower than the pre-storm value, or homeowners received insufficient funds to rebuild if the pre-storm value was less than the actual cost of damage. Under this formula, owners of identical homes with similar storm damage and repair estimates would receive very different grant awards based on where they lived (Bates and Green 2009). Because African Americans in New Orleans generally live in historically segregated neighborhoods with depressed property values, they received smaller Road Home compensation awards and therefore a fraction of the funds needed to rebuild their homes. As a result, many homeowners have not been able to complete repairs to their homes and move back into their communities.

Post-Katrina rebuilding decisions and policies that perpetuate social inequalities are spawning not-in-my-backyard (NIMBY) movements dedicated to preserving pre-Katrina 
demographic patterns. Three examples are noteworthy. First, in October 2006, the Greater New Orleans Fair Housing Action Center filed a federal lawsuit to overturn a suburban St. Bernard Parish ordinance that prohibits owners from renting to anyone who is not a blood relative. The suit contends that the ordinance, passed after the storm, will perpetuate segregation and reinforce the predominantly white character of the parish (Rioux 2006). Second, in 2006, the suburban Jefferson Parish Council passed a resolution objecting to any applications by developers to use federal tax credits to build government subsidized low-income housing (Gordon 2006). Third, since 2005, homeowners and legislators have attempted to block efforts by developers and fair-housing advocates to build new multifamily housing developments in New Orleans East, a heavily flooded area of the city. Several attempts by the city council to pass blanket moratoria on such affordable housing led to claims of discrimination and threats of legal action, eventually forcing the city council to abandon such efforts. Leaders from New Orleans East, who are disproportionately middle class and upper middle class African Americans with economic and political clout, have attempted to ban new multifamily developments, saying a glut of them has turned the once solidly middle class area into a dumping ground for the poor and thereby has destroyed property values and increased crime. The three cases together illustrate that class as well as race motivate the various civic attempts to perpetuate social inequities (Hammer 2009).

Political mobilization against affordable housing both reflects and reinforces segregationist housing patterns, and complicates efforts to rebuild neighborhoods. Scholars have long recognized that housing policies and real estate practices that preserve and enhance affordable housing are critical for the socioeconomic resilience of neighborhoods (Wallace and Wallace 2008). In New Orleans, current policies and decisions are exacerbating the housing problems caused by the disaster as skyrocketing rents and housing costs are burdening not only the poor but the working and middle classes.

Cross-scale linkages can promote social antagonisms if communities believe that government agencies are withholding vital information, elected officials are dishonest, or government agencies distribute resources unfairly or unequally. Over the last several years, coalitions of neighborhood residents in the Lower Ninth Ward have complained about the dearth of recovery projects in the struggling community. Residents have complained that city leaders have misappropriated recovery money to create new amenities in other neighborhoods, while their infrastructure remains devastated. City leaders acknowledged certain disparities but held that FEMA had not approved federal financing for recovery projects in the neighborhood. For some residents, incomplete information fuels perceptions that city leaders are dishonest and exploitative (Krupa 2010).
The above examples corroborate the work of Adgar et al. (2006) and Ernstson et al. (2010a), who note that legitimacy and efficacy of governance systems depends on equitable distribution of benefits from cross-scale linkages through the mechanisms of accountability, transparency, and trust. Information asymmetries that derive from knowledge concealment, restraint, and unequal control are not likely to generate sustainable development or facilitate social learning in cross-scale interactions. If government regulators, for example, mobilize information and resources from cross-level interactions to reinforce their authority, other stakeholders, such as resource users, are often disempowered. Information and knowledge asymmetries within the social-ecological governance system have reinforced inequalities, intensified conflicts, and bolstered enmity and distrust. These problems have complicated recovery effort, slowed long-term rebuilding, reinforced vulnerabilities, and weakened socialecological resilience.

\section{CONCLUSION}

We have examined the extension, intensification, and acceleration of cross-scale interactions as major forces shaping patterns and processes of social-ecological vulnerability and resilience in the New Orleans urban ecosystem. Cross-scale interactions are the communicatory infrastructure through which information, resources, and other forms of capital flow. How social-ecological processes interact over temporal and spatial scales is one of the key factors in the resilience and vulnerability of different parts of a social-ecological system, whether it is an urban community or a natural ecosystem. The usefulness of the concepts of vulnerability and resilience lie in the attempt to separate extralocal patterns and regularities from the context-laden urban environment, and reveal the reciprocal feedback effects of human action and urban ecosystem transformation. We provided a conceptual framework to assess the impact of government policies, programs, and other forms of activity on the transformation of organizational couplings in a dynamic urban ecosystem. Different socio-legal regulations and government policies have helped constitute and shape various cross-scale linkages that both promote resilience and vulnerability in the New Orleans urban ecosystem.

Traumatic events and disasters alter organizational couplings in social-ecological systems by extending, intensifying, and accelerating cross-scale interactions. By creating and extending linkages among diverse agents and institutions, cross-scale interactions have enabled the different components of the New Orleans urban ecosystem to take advantage of opportunities, leverage resources, and learn from activities happening in other components. Our findings buttress the work of Young et al. (2006:309), who assert that "the existence of many interconnections may enhance the robustness or resilience of large-scale [social-ecological systems] by diluting and distributing the impact of strong changes in 
individual elements upon other elements of the system." Cross-scale interactions have linked social and technical networks to activate and sustain processes of self-organization and social learning for innovation and progressive transformation. Trust, cooperation, and sharing of information and resources has been necessary to implement policies and management actions to build knowledge, incentives, and learning capabilities into institutions and organizations for post-Katrina recovery and rebuilding (Folke et al. 2005, Gunderson and Folke 2005). Overall, our analysis supports Turner et al. (2003), who argue that resilience is not the flip side or opposite of vulnerability. Different socio-legal regulations and government policies have helped constitute and shape various cross-scale linkages that both promote resilience and vulnerability in the New Orleans urban ecosystem.

At the same time, our analysis demonstrates that cross-scale interactions can produce maladaptive couplings or negative feedbacks that perpetuate social inequalities and reinforce socio-spatial vulnerabilities to stress and trauma. This insight reinforces Adger et al. (2006:12), who note that cross-scale interactions "are by no means a zero-sum game." Rather, some linkages and connections "emerge that radically alter the playing field while others reinforce existing inequalities between powerful and less powerful players." Cross-scale linkages that promote and legitimize exclusionary policies, environmentally destructive growth practices, and exploitative land use decisions degrade resilience to disasters. Currently, contested property rights, land claims, and land use planning processes both complicate and problematize the adaptive capacity of communities in the metropolitan region and could jeopardize long-term efforts to restore the wetlands ecosystem. Furthermore, if social and political institutions do not promote more equitable and sustainable forms of development, it is less likely that communities will be able to adapt and respond effectively to future trauma. How institutions define and allocate property rights and develop water and land use planning practices is important for community adaptive capacity because they influence access to resources, wealth, well-being, and livelihood.

Finally, the integrated vulnerability-resilience perspective we have adopted suggests a multiscale approach to understanding the drivers of urban susceptibility and adaptive capacity in urban ecosystems. Social and natural systems are deeply interwoven, and their dynamics of change are uneven and long term. Patterns and processes of resilience and vulnerability involve complex relationships among political, socioeconomic, and cultural elements that vary across a range of temporal and spatial scales. Cross-scale interactions shape the socioeconomic and institutional conditions that constrain and enable effective response and adaptation to stress and perturbation for socialecological systems. Yet we lack knowledge of how cross-scale interactions can stabilize some social-ecological components, degrade and/or improve other components, and affect the pace and trajectory of urban ecosystem transformation. Wars, economic and financial crises, major shifts in food and fuel prices, technological changes, and land use policy are large in magnitude, spatially extensive, and transform socialecological systems over long time periods. Infrequent events can radically alter trends and disrupt prevailing cross-scale interactions to the detriment of some communities and benefit of other communities. Individual cases may be unique, and our ability to generalize or predict may be severely limited. Understanding how cross-scale interactions affect extensive, pervasive, and subtle change is therefore one of the most important challenges for urban ecosystem science.

\section{RESPONSES TO THIS ARTICLE}

Responses to this article are invited. If accepted for publication, your response will be hyperlinked to the article. To submit a response, follow this link. To read responses already accepted, follow this link.

\section{ACKNOWLEDGMENTS}

Support for this research came from the National Science Foundation (NSF).

\section{LITERATURE CITED}

Adger, N. W. 2006. Vulnerability. Global Environmental Change 16:268-281.

Adger, N. W., K. Brown, and E.L. Tompkins. 2006. The political economy of cross-scale networks in resource comanagement. Ecology and Society 10(2):9. [online] URL: http://www.ecologyandsociety.org/vol10/iss2/art9

Auyero, J., and D. Swistun. 2008. The social production of toxic uncertainty. American Sociological Review. 73:357. http://dx.doi.org/10.1177/000312240807300301

Bankoff, G. 2003. Cultures of disaster: society and natural hazard in the Philippines. Routledge, London, UK.

Bankoff, G. 2007. Comparing vulnerabilities: toward charting an historical trajectory of disasters. Historical Social Research 32(3):103-114.

Bates, L. K., and R. A. Green. 2009. Housing recovery in the Ninth Ward: disparities in policy, process, and prospects. Pages 229-245 in R. D. Bullard and B. Wright, editors. Race, place, and environmental justice after Hurricane Katrina: struggles to reclaim, rebuild, and revitalize New Orleans and the Gulf Coast. Westview Press, Boulder, Colorado, USA.

Berke, P. R., and T. J. Campanella. 2006. Planning for postdisaster resiliency. The Annals of the American Academy of Political and Social Science 604(1):192-207. http://dx.doi. org/10.1177/0002716205285533

Berkes, F. 2002. Cross-scale institutional linkages: perspectives from the bottom up. In E. Ostrom, T. Dietz, N. 
Dolsak, P. C. Stern, S. Stonich, and E. U. Weber, editors. The drama of the commons. National Academy Press, Washington, D.C., USA.

Berkes, F., J. Colding, and C. Folke, editors. 2003. Navigating social-ecological systems: management practices and social mechanisms for building resilience. Cambridge University Press, Cambridge, UK.

Blaikie, P., T. Cannon, I. Davis, and B. Wisner. 1994. At risk: natural hazards, people's vulnerability and disasters. Routledge, New York, New York, USA.

Boyd, E. 2006. Community Development Block Grant funds in disaster relief and recovery. CRS report for Congress. RL33330. April 25, 2006.

Brand, F. S., and K. Jax. 2007. Focusing the meaning(s) of resilience: resilience as a descriptive concept and a boundary object. Ecology and Society 12(1):23. [online] URL: http://w ww.ecologyandsociety.org/vol12/iss1/art23/

Cash, D. W., W. Adger, F. Berkes, P. Garden, L. Lebel, P. Olsson, L. Pritchard, and O. Young. 2006. Scale and crossscale dynamics: governance and information in a multilevel world. Ecology and Society 11(2):8. [online] URL: http://ww w.ecologyandsociety.org/vol11/iss $2 /$ art8/

Comfort, L. K. 1999. Shared risk: complex systems in seismic response. Elsevier, Oxford, UK.

Comfort, L. K. 2005. Risk, security, and disaster management. Annual Review of Political Science 8:335-356.

Corporation for National and Community Service. 2005. Semiannual regulatory agenda. Federal Register 70(209). October 31, 2005. [online] URL: http://www.americorps.gov/ for_organizations/funding/nofa_detail.asp?tbl_nofa_id=15

Cutter, S. 2001. American hazardscapes: the regionalization of hazards and disasters. Joseph Henry Press, Washington, D. C., USA.

Dang, T. D., and J. Burris. 2005. On the Internet, offers of assistance. Baltimore Sun, September 2, 2005.

Downing, T. E., J. Aerts, J. Soussan, O. Barthelemy, S. Bharwani, C. Ionescu, J. Hinkel, R. J. T. Klein, L. J. Mata, N. Martin, S. Moss, D. Purkey, and G. Ziervogel. 2005. Integrating social vulnerability into water management. SEI Working Paper and Newater Working Paper No. 4. Stockholm Environment Institute, Oxford, UK.

Dwyer, J., and C. Drew. 2005. Fear exceeded crime's reality in New Orleans. New York Times, September 29, 2005.

Dynes, R. R., and H. Rodriguez. 2007. Finding and framing Katrina: the social construction of disaster. Pages 23-33 in D. L. Brunsma, D. Overfelt, and J. S. Picou, editors. The sociology of Katrina: perspectives on a modern catastrophe. Rowman $\&$ Littlefield, New York, New York, USA.
Eakin, H., and A. L. Luers. 2006. Assessing the vulnerability of social-environmental systems. Annual Review of Environment and Resources 31:365-394. http://dx.doi.org/10 .1146/annurev.energy.30.050504.144352

Ernstson, H., S. Barthel, E. Andersson, and S. T. Borgström. 2010a. Scale-crossing brokers and network governance of urban ecosystem services: the case of Stockholm. Ecology and Society 15(4):28. [online] URL: http://www.ecologyandsociety. org/vol15/iss4/art28/

Ernstson, H., S. E. van der Leeuw, C.L. Redman, D. J. Meffert, G. Davis, C. Alfsen, and T. Elmqvist. 2010b. Urban transitions: on urban resilience and human-dominated ecosystems. Ambio. DOI: 10.1007/s13280-010-0081-9

Figley, C. R. 2009. Editorial. Traumatology 15(2):1-6. http:// dx.doi.org/10.1016/S0141-1136(00)00246-4

Folke, C. 2006. Resilience: the emergence of a perspective for social-ecological systems analyses. Global Environmental Change 16:253-267. http://dx.doi.org/10.1016/j.gloenvcha.2 $\underline{006.04 .002}$

Folke, C. 2007. Social-ecological systems and adaptive governance of the commons. Ecological Research. 22(1):1415. http://dx.doi.org/10.1007/s11284-006-0074-0

Folke, C., T. Hahn, P. Olsson, and J. Norberg. 2005. Adaptive governance of social-ecological systems. Annual Review of Environment and Resources 30:441-473. http://dx.doi.org/10 .1146/annurev.energy.30.050504.144511

Freudenburg, W. R. 1993. Risk and recreancy: Weber, the division of labor, and the rationality of risk perceptions. Social Forces 71:909-932. http://dx.doi.org/10.2307/2580124

Freudenburg, W. R., S. Frickel, and R. Grambling. 1995. Beyond the nature/society divide: learning to think about a mountain. Sociological Forum 94(1):89-114. http://dx.doi.or $\mathrm{g} / 10.1007 / \mathrm{BF} 02095827$

Freudenburg, W. R., R. Gramling, S. Laska, and K. Erikson 2009. Catastrophe in the making: the engineering of Katrina and the disasters of tomorrow. Island Press, New York, New York, USA.

Gallopín, G. C. 2006. Linkages between vulnerability, resilience, and adaptive capacity. Global Environmental Change 16(3):293-303. http://dx.doi.org/10.1016/j.gloenvch a.2006.02.004

Gordon, M. 2006. More housing for poor opposed; Roberts says that those from city are unwelcome. Times-Picayune, October 19, 2006.

Gotham, K., and M. Greenberg. 2008. From 9/11 to 8/29: postdisaster recovery and rebuilding in New York and New Orleans. Social Forces 87(2):1037-1062.

Government Accountability Office (GAO). 2007. Nonprofit sector: increasing numbers and key role in delivering federal 
services. Statement of Stanley J. Czerwinski Director, Strategic Issues. Testimony before the Subcommittee on Oversight, Committee on Ways and Means, House of Representatives. GAO-07-1084T. Government Accountability Office, Washington, D.C., USA.

Government Accountability Office (GAO). 2010. Hurricane recovery: federal government provided a range of assistance to nonprofits following hurricanes Katrina and Rita. GAO-10-800. Government Accountability Office, Washington, D.C., USA.

Grimm, N. B., J. M. Grove, S. T. A. Pickett, and C. L. Redman. 2000. Integrated approaches to long-term studies of urban ecological systems. BioScience 50(7):571-584. http://dx.doi. org/10.1007/978-0-387-73412-5 8

Grimm, N. B., and C. L. Redman. 2004. Approaches to the study of urban ecosystems: the case of Central ArizonaPhoenix. Urban Ecosystems 7:100-213. http://dx.doi.org/10. 1023/B:UECO.0000044036.59953.a1

Gunderson, L. 2010. Ecological and human community resilience in response to natural disasters. Ecology and Society 15(2):18. [online] URL: http://www.ecologyandsociety.org/vol15/ iss $2 / \operatorname{art} 18 /$

Gunderson, L., and C. Folke. 2005. Resilience-now more than ever. Ecology and Society 10(2):22. [online] URL: http: //www.ecologyandsociety.org/vol10/iss2/art22/

Hammer, D. 2009. Homeowners, legislators battle eastern New Orleans apartments. Times-Picayune, January 22, 2009.

Holling, C. S. 1986. The resilience of terrestrial ecosystems: local surprise and global change. Pages 292-317 in W. C. Clark and R. E. Munn, editors. Sustainable development of the biosphere. Cambridge University Press, Cambridge, UK.

Holling, C. S. 2001. Understanding the complexity of economic, ecological, and social systems. Ecosystems 4:390405. http://dx.doi.org/10.1007/s10021-001-0101-5

Kasperson, R. E., K. Dow, E. R. M. Archer, D. Cáceres, T. E. Downing, T. Elmqvist, S. Eriksen, C. Folke, G. Han, K. Iyengar, C. Vogel, K. A. Wilson, and G. Ziervogel. 2005. Vulnerable people and places. Chapter 6 in Ecosystems and human well-being: current state and trends assessment. Millennium Ecosystem Assessment. Island Press, Washington, D.C., USA.

Klinenberg, E. 2002. Heat wave: a social autopsy of disaster in Chicago. Chicago University Press, Chicago, Illinois, USA.

Krupa, M. 2010. N.O. to analyze recovery outlay; Lower 9 got less than was promised. Times-Picayune, July 25, 2010. http://dx.doi.org/10.1007/BF02051989
Liu, J., T. Dietz, S. R. Carpenter, M. Alberti, C. Folke, E. Moran, A. N. Pell, P. Deadman, T. Kratz, J. Lubchenco, E. Ostrom, Z. Ouyang, W. Provencher, C. L. Redman, S. H. Schneider, and W. W. Taylor. 2007. Complexity of coupled human and natural systems. Science 317(5844):1513-1516. http://dx.doi.org/10.1126/science.1144004

Liu, A., and A. Plyer. 2010. An overview of greater New Orleans: from recovery to transformation in The New Orleans Index at Five. Brookings Institution and Greater New Orleans Community Data Center, Washington, D.C., USA.

Louisiana Association of Nonprofit Organizations (LANO). 2005. Anпual report, 2005. Louisiana Association of Nonprofit Organizations (LANO), Baton Rouge, Louisiana, USA. http://dx.doi.org/10.1525/jlca.1989.1.1.25.1

Masten, A. S., and J. Obradovic. 2007. Disaster preparation and recovery: lessons from research on resilience in human development. Ecology and Society 13(1):9. [online] URL: http://www.ecologyandsociety.org/vol13/iss1/art9/

Miller, F., H. Osbahr, E. Boyd, F. Thomalla, S. Bharwani, G. Ziervogel, B. Walker, J. Birkmann, S. Van der Leeuw, J. Rockström, J. Hinkel, T. Downing, C. Folke, and D. Nelson. 2010. Resilience and vulnerability: complementary or conflicting concepts? Ecology and Society 15(3):11. [online] URL: http://www.ecologyandsociety.org/vol15/iss3/art11/

Mutter, J. 2010. Disasters widen the rich-poor gap. Nature 466:1042. http://dx.doi.org/10.1038/4661042a

Newman, L. L., and A. Dale. 2005. Network structure, diversity, and proactive resilience building: a response to Tompkins and Adger. Ecology and Society 10(1):r2. [online] URL: http://www.ecologyandsociety.org/vol10/iss1/resp2/

Noguchi, Y. 2005. Good Samaritans turn to web to help victims. Washington Post, September 2, 2005.

Nolan, B. 2009. Katrina's devastation rewrote the playbook; local groups say relief about half finished. Times Picayune, July 26, 2009. [online] URL: http://www.nola.com/news/index. ssf/2009/07/katrinas_devastation_rewrote_t.html

Norris, F. H., S. P. Stevens, B. Pfefferbaum, K. F. Wyche, and R. L. Pfefferbaum. 2008. Community resilience as a metaphor, theory, set of capacities, and strategy for disaster readiness. American Journal of Community Psychology 41:127-150. http://dx.doi.org/10.1007/s10464-007-9156-6

Olsson, P., C. Folke, and F. Berkes. 2004. Adaptive comanagement for building resilience in social-ecological systems. Environmental Management 34:75-90. http://dx.doi. org/10.1007/s00267-003-0101-7

Olsson, P., L. H. Gunderson, S. R. Carpenter, P. Ryan, L. Lebel, C. Folke, and C. S. Holling. 2006. Shooting the rapids: navigating transitions to adaptive governance of social- 
ecological systems. Ecology and Society 11(1):18. [online] URL: http://www.ecologyandsociety.org/vol11/iss1/art18/

Pelling, M. 2003. The vulnerability of cities: natural disasters and social resilience. Earthscan Publications, London, UK.

Perrow, C. A. 1997. Organizing for environmental destruction. Organization \& Environment 10:66-72.

Pickett, S. T. A., M. L. Cadenasso, J. M. Grove, C. H. Nilon, R. V. Pouyat, W. C. Zipperer, and R. Costanza. 2001. Urban ecological systems: linking terrestrial, ecological, physical, and socioeconomic components of metropolitan areas. Annual Review of Ecological Systems 32:127-157. http://dx.doi.org/1 0.1146/annurev.ecolsys.32.081501.114012

Pierre, R. E., and A. Gerhart. 2005. News of pandemonium may have slowed aid; unsubstantiated reports of violence were confirmed by some officials, spread by news media. Washington Post, October 5, 2005.

Plyer, A., and R. Campanella. 2010. Job sprawl in metropolitan New Orleans: based on 2008 local employment dynamics data from the U.S. Census Bureau. Greater New Orleans Community Data Center (GNOCDC), New Orleans, Louisiana, USA. [online] URL: http://www.gnocdc.org/JobS prawl/index.html

Resilience Alliance. 2009. Assessing resilience in socialecological systems: a workbook for practitioners. Revised Version 2.0. [online] URL: http://www.resalliance.org/index. php/resilience assessment

Rioux, P. 2006. St. Bernard sued over rent limit; group says new law upholds segregation. Times-Picayune, October 6, 2006. http://dx.doi.org/10.1002/ardp.18681840311

Swyngedouw, E. 2004. Social power and the urbanization of water: flows of power. Oxford University Press, New York, New York, USA.

Thevenot, B. 2005. Myth-making in New Orleans. American Journalism Review 27(6):30-37.

Thevenot, B., and G. Russell. 2005. Rape, murder, gunfights; for three anguished days the world's headlines blared that the Superdome and convention center had descended into anarchy. Times-Picayune, September 26, 2005.

Tierney, K., C. Bevc, and E. Kuligowski. 2006. Metaphors matter: disaster myths, media frames, and their consequences in Hurricane Katrina. Annals of the American Academy of Political and Social Science 604:57-81. http://dx.doi.org/10. $\underline{1177 / 0002716205285589}$

Tompkins, E. L., and W. N. Adger. 2004. Does adaptive management of natural resources enhance resilience to climate change? Ecology and Society 9(2):10. [online] URL: http://w ww.ecologyandsociety.org/vol9/iss $2 / \operatorname{art10}$
Tompkins, E., W. N. Adger, and K. Brown. 2002. Institutional networks for inclusive coastal zone management in Trinidad and Tobago. Environment and Planning A. 34:1095-1111.

Turner, B. L., II, R. E. Kasperson, P. A. Matson, J. McCarthy, R. W. Corell, L. Christensen, N. Eckley, J. X. Kasperson, A. Luers, M. L. Martello, C. Polsky, A. Pulsipher, and A. Schiller. 2003. A framework for vulnerability analysis in sustainability science. Proceedings of the National Academy of Sciences 100 (14):8074-8079. http://dx.doi.org/10.1073/pnas.1231335100

U.S. Department of Housing and Urban Development (HUD). 2006. Disaster recovery initiative. Federal Register 71(29). Department of Defense Appropriations Act, 2006.

U.S. Long Term Ecological Research Network (LTER). 2007. The decadal plan for LTER: integrative science for society and the environment. LTER Network Office Publication Series No. 24, Albuquerque, New Mexico, USA.

Walker, B., and J. A. Meyers. 2004. Thresholds in ecological and social-ecological systems: a developing database. Ecology and Society 9(2):3. [online] URL: http://www.ecolog yandsociety.org/vol9/iss2/art3/

Wallace, D., and R. Wallace. 2008. Urban systems during disasters: factors for resilience. Ecology and Society 13(1):18. [online] URL: http://www.ecologyandsociety.org/vol13/iss1/ $\underline{\operatorname{art} 18 /}$

Young, O. R., F. Berkhout, G. C. Gallopin, M. A. Janssen, E. Ostrom, and S. van der Leeuw. 2006. The globalization of socio-ecological systems: an agenda for scientific research. Global Environmental Change 16:304-316. http://dx.doi.org /10.1016/j.gloenvcha.2006.03.004 